\title{
Kilka uwag o terenowym badaniu amatorskich klubów piłkarskich (w nastającej erze postpandemicznej)
}

\author{
Konrad Burdyka \\ Instytut Rozwoju Wsi i Rolnictwa PAN
}

DOI: http://dx.doi.org/10.18778/1733-8069.17.1.02

Słowa kluczowe:

klub piłkarski,

wieś, metodologia,

pandemia

\begin{abstract}
Abstrakt: Studia empiryczne w obszarze socjologii sportu cechuje ponadprzeciętna trudność realizacji in situ, objawiająca się chociażby ograniczonym dostępem do materiału badawczego i ograniczoną możliwością jego porównań. Jak zauważył w swym klasycznym już opracowaniu Klaus Heinemann (1989), problemy te wynikają (a) ze zróżnicowania modeli nowożytnego sportu i form jego społecznego zakorzenienia oraz (b) ze specyfiki organizacji sportowych - obecnie polifunkcyjnych, działających nieraz w skrajnie odmiennych środowiskach społecznych. Celem artykułu jest prezentacja wybranych problemów metodologicznych zaistniałych w toku etnograficznego oglądu amatorskich klubów piłkarskich działających na obszarach wiejskich w Polsce. Autor podejmuje również próbę odniesienia doświadczeń wyniesionych z realizacji tego przedsięwzięcia do sytuacji postpandemicznej. Artykuł może być tym samym potraktowany jako głos w dyskusji nad użytecznością instrumentarium jakościowego w studiach nad współczesnym sportem.
\end{abstract}

Konrad Burdyka, doktor nauk społecznych, adiunkt w Zakładzie Antropologii Kultury Wsi IRWiR PAN. W obszarze jego zainteresowań badawczych znajdują się wiejskie organizacje pozarządowe (LZS, OSP, KGW) oraz niematerialne dziedzictwo kulturowe (zabawy i gry tradycyjne). Pełni funkcję przewodniczącego Sekcji Socjologii Wsi i Rolnictwa PTS oraz zasiada w Komisji Sportu Wiejskiego PKOl.

\author{
Adres kontaktowy: \\ Instytut Rozwoju Wsi i Rolnictwa \\ Polska Akademia Nauk \\ Zakład Antropologii Kultury Wsi \\ ul. Nowy Świat 72 \\ 00-330 Warszawa \\ e-mail: kburdyka@wp.pl
}


ocjologowie wsi - często analizujący style życia lub przejawy obywatelskości na obszarach wiejskich - nie wykazują zainteresowania kulturą fizyczną polskiej prowincji. Brak inklinacji do wychodzenia poza wielkomiejski stadion przejawiają również badacze sportu ujmowanego jako fenomen socjologiczny. Za symptomatyczny wypada uznać fakt, że wątków wiejskich nie podjęto (nie licząc raportów dotyczących funkcjonowania boisk typu Orlik) w publikacjach powstałych na fali wznieconej $\mathrm{w}$ Polsce przez piłkarskie Mistrzostwa Europy UEFA Euro 2012 (por. Stempień 2018). Atrakcyjności tematyce nie przydały też (jak dotąd) najnowsze, zainicjowane po 2015 roku przedsięwzięcia polityki publicznej względem „ssportu dla wszystkich”. Rosnący strumień środków z kasy państwa trafia obecnie do małych, amatorskich klubów sportowych - jednej z najliczniejszych kategorii trzeciego sektora, o której polska socjologia wciąż mówi niewiele. Zaryzykować można stwierdzenie, że niedostatek naukowych studiów nad kulturą fizyczną w kontekście wiejskim idzie w parze $\mathrm{z}$ tabloidyzacją: popularna wiedza o kluczowych aktorach sportu wiejskiego opiera się bądź na nostalgicznych nawiązaniach do „złotego wieku” Ludowych Zespołów Sportowych, bądź na sensacyjno-humorystycznych - rozpowszechnianych głównie za pomocą Internetu i mediów społecznościowych - doniesieniach z amatorskich rozgrywek piłkarskich. Uwypukla się w nich nazwy drużyn, wiek i profesję zawodników, mniej lub bardziej sensacyjne wydarzenia z boiska. W efekcie eksplikacje zjawiska o ogromnym, sądząc ze statystyki publicznej, zasięgu społecznego oddziaływania są przerysowane w swej formie i uproszczone $\mathrm{w}$ treści (problem ten sam w sobie wydaje się ciekawy z perspektywy analizy dyskursu).

W świetle powyższej refleksji warto zadać pytanie: z czego wynika zasygnalizowany brak entuzjazmu do socjologicznych/antropologicznych eksploracji wiejskiego sportu we współczesnej Polsce? W ocenie autora jedną z kluczowych przyczyn takiego stanu rzeczy jest dostrzegana przez badaczy relatywnie duża trudność metodologiczna (rozumiana tutaj jako zbiór dylematów pojawiających się na etapie operacjonalizacji i pomiaru) jakościowych studiów podejmowanych wokół rywalizacji sportowej. Przykładowo: socjologowie skupieni na eksplikacjach zachowań kibiców piłkarskich w dużych miastach sygnalizują problemy z przekładalnością perspektyw, z rozdzieleniem roli badacza-obserwatora i badacza-uczestnika wydarzeń sportowych oraz niebezpieczeństwa związane z "pełnym zanurzeniem” we wspólnocie widowiska (por. Kossakowski, Antonowicz, Szlendak 2012). Poza metropolią ujawniają się dodatkowe trudności, bowiem kluby tam działające stanowią na ogół małe grupy społeczne o wysokim poziomie integracji wewnętrznej i niskim stopniu sformalizowania (obejmujące zarówno zawodników, jak też fanów), są przy tym silnie zakorzenione lokalnie. Badanie wiejskich klubów nieodzownie wiąże się więc z etnograficznym opisem lokalnego uniwersum symbolicznego, czyli kontekstu ich działalności. Taki sposób procedowania wydaje się wskazany zarówno w procesie deskrypcji, jak też zrozumienia i wyjaśniania, bowiem tylko wówczas uzyskać można pełen obraz złożoności szeregu zjawisk generowanych przez organizacje sportowe, obraz ich miejsca w życiu jednostek oraz korelacji z innymi elementami składowymi układu lokalnego (por. Lutyński 2000: 299-300). Konstatacja ta współgra z ogólnie podzielaną opinią Klausa Heinemanna (1989: 140-141) o ponadprzeciętnej złożoności studiów empirycznych podejmowanych $\mathrm{w}$ obszarze socjologii sportu. W praktyce badawczej znaczy to ni mniej, ni więcej, że konieczny do poniesienia przez rzetelnego socjologa sportu nakład pracy w gromadzeniu danych uchodzi za niewspółmiernie wysoki do spo- 
dziewanej wagi rezultatów teoretycznych (zwłaszcza jeśli przyjmie się, że sport na polskiej wsi - a zwłaszcza piłka nożna - pozostaje odbiciem fenomenów dostrzegalnych na i wokół łatwo dostępnego wielkomiejskiego stadionu). Z dużą dozą prawdopodobieństwa trzeba stwierdzić, że nakład ten nie zmaleje w dającej się przewidzieć przyszłości - konsekwencje pandemii SARS Cov-19 wydłużą realizację przedsięwzięć in vivo i wymuszą zmianę podejścia metodologicznego (Fine, Abramson 2020: 167-168).

Autor stoi na stanowisku, że na wzrost zainteresowania tematyką sportu prowincjonalnego wpłynać może wszystko to, co usprawni przebieg procesu badawczego w realiach rustykalnych. Celem niniejszego tekstu jest więc prezentacja wybranych problemów natury metodologicznej zaistniałych w toku realizacji jakościowego studium wiejskich klubów piłkarskich. Przedstawione rozwiązania zostały odniesione do wyzwań, przed którymi prawdopodobnie $-\mathrm{w}$ intuicji autora - staną badacze organizacji sportowych $\mathrm{w}$ dobie postpandemicznej. Popełniony wybór zagadnień jest, siłą rzeczy, subiektywny i silnie skontekstualizowany (wskazane dylematy nie muszą być powszechnie doświadczane). $\mathrm{Z}$ tego powodu nie należy traktować go jako uniwersalną instrukcję postępowania. Niemniej autor ma nadzieję, że artykuł pozwoli zainteresowanym badaczom uniknąć przynajmniej części pułapek i ślepych zaułków w badaniu wiejskiego sportu, a przez to wpłynie na jakość studium determinowaną między innymi przez świadomość ograniczeń, słabych punktów oraz wpływu osoby badacza na przebieg procesu gromadzenia danych (Gibbs 2011: 163-166).

\section{Opis projektu badawczego}

Bazą do czynionych tutaj refleksji jest projekt badawczy realizowany w latach 2012-2014 dzięki granto- wi $\mathrm{NCN}^{1}$. Przedsięwzięciu przyświecały dwa cele ogólne: (1) opisowo-wyjaśniający, zmierzający do deskrypcji strategii umożliwiających klubom piłkarskim efektywne działanie między innymi w otoczeniu zdominowanym przez Ochotnicze Straże Pożarne (za podstawową kategorię pojęciową opisu obrano kapitał społeczny) oraz (2) eksploracyjny (poznawczy), zmierzający do odkrycia elementów kultury symbolicznej, które są wytwarzane wokół klubu piłkarskiego (posłużono się $\mathrm{w}$ tym celu pojęciem futbolizacji, zdefiniowanym na potrzeby projektu jako: proces implementacji treści kultury, takich jak symbole, rytuały, znaczenia, wytworzonych w ścisłym związku z dyscypliną sportową, jaką jest piłka nożna, w pozasportowe przestrzenie życia społecznego).

Badanie realizowano $\mathrm{w}$ dwóch regionach centralnej Polski, zróżnicowanych ze względu na złożoność struktury organizacyjnej piłkarstwa, poziom kapitału społecznego (szacowany na poziomie gmin) oraz spoistość kulturową danego obszaru (występowanie silnej tożsamości i tradycji regionalnych oraz kotwic kulturalnych). Na wytypowanych obszarach dokonano celowego doboru ośmiu klubów piłkarskich (po cztery na dany obszar) rywalizujących $\mathrm{w}$ tak zwanych niższych ligach. Wybierając kluby, autor podążał za radą Charlesa Wright Millsa (2007: 326-327), aby poszukiwać skrajnych, "biegunowych typów”. Za zmienne różnicujące obiekty badania uznano:

1. poziom aktywności organizacji - szacowany w oparciu o autorski koncept „wskaźnika członkostwa" (iloraz liczby aktywnych członków klubów - zawodników figurujących w oficjalnym rejestrze Polskiego Związku Piłki Nożnej - do liczby ludności męskiej predystynowanej do gry

\footnotetext{
${ }^{1}$ Projekt badawczy został sfinansowany ze środków Narodowego Centrum Nauki, przyznanych na podstawie decyzji DEC-2011/03/N/HS6/04934.
} 
w piłkę nożną na poziomie seniorskim, dookreślonej przedziałem wieku: 15-64 lat). W założeniu: im wyższa wartość wskaźnika, tym aktywniejszy klub, ponieważ potrafi przyciągnąć w swoje szeregi liczne grono piłkarzy.

2. czas życia organizacji - wartość tej zmiennej określono, wskazując datę powstania klubu, a gdy nie było to możliwe (kronikarstwo w środowisku LZS nie jest zjawiskiem powszechnym), wówczas poprzez obliczenie długości ostatniego okresu nieprzerwanej działalności stowarzyszenia (wykorzystano zasoby strony internetowej 90minut.pl). Przyjęto założenie, że organizacje „stare”, założone przed rokiem 1989, wykazywać powinny inne style działania niż „młode”, funkcjonujące od swego początku w realiach wolnorynkowych.

Wyniki zrealizowanych badań zostały w sposób możliwie kompleksowy zaprezentowane w opracowanej przez autora monografii (Burdyka 2019). Spośród głównych wniosków badawczych warto przywołać te odnoszące się do wyjściowych hipotez przedsięwzięcia: (a) trwanie i skuteczne działanie wiejskich organizacji o profilu sportowym możliwe jest dzięki wykorzystaniu indywidualnego kapitału społecznego partycypujących w nich osób, jak również (b) w środowisku rustykalnym organizacje pozarządowe o profilu sportowym generują i wzmacniają tożsamość wspólnotową społeczności lokalnej.

\section{Wybrane problemy zaistniałe $\mathrm{w}$ trakcie badań}

\section{Ustalenie harmonogramu wyjazdów badawczych (ograniczenia temporalne)}

Za truizm uznać należy stwierdzenie, że czas stanowi dziś najcenniejszy zasób w posiadaniu każde- go naukowca. Rzeczywistość projektowa, w której pracują uzależnieni od publicznych środków badacze (zwłaszcza rozpoczynający kariery), obliguje do strukturyzacji inicjatyw naukowych za pomoca sztywnych terminów, momentów kluczowych oraz okresów rozliczeń grantów i dotacji. Realizacja finansowanych $\mathrm{w}$ ten sposób przedsięwzięć jakościowych staje się utrudniona niemalże co do swej istoty, bowiem tylko długotrwała obecność badacza w środowisku eksploracji skutkuje dogłębnym - rzetelnym i trafnym - poznaniem danego świata społecznego i typowych dlań zjawisk (por. Dobrowolski 1966: 120-121). Nawet dysponując relatywnie dużym budżetem, pozwalającym prowadzić kilka zadań badawczych współbieżnie, zmierzyć się trzeba choćby z periodycznością pewnych fenomenów - ich ciągła obserwacja okazuje się współcześnie niemożliwa (Hammersley, Atkinson 2000: 58; Flick 2011: 157).

W opisywanym projekcie komplikacja temporalna wystąpiła już na samym początku fazy empirycznej i miała daleko idący wpływ na sposób gromadzenia i rodzaj pozyskanych materiałów. U podstaw trudności związanych z planowaniem pobytu w poszczególnych miejscowościach (siedzibach wytypowanych klubów) stał immanentny dla wszelkich zorganizowanych form uczestnictwa w sporcie kalendarz rywalizacji - określający krótko i średniookresowe cykle życia klubów oraz aktywności ich szeregowych członków. W przypadku wiejskich klubów piłkarskich owe momenty skupień były relatywnie krótkotrwałe i niemal zawsze dotyczyły weekendów. Sobota i niedziela to główne dni zawodów futbolowych w niższych ligach. Wtedy odbywają się mecze „u siebie” oraz „wyjazdy”, dochodzi przy tym do fundamentalnych dla istnienia klubu interakcji zawodników, działaczy i kibiców (w dni robocze zaprzątniętych pracą lub szkołą). W czasie 
wolnym stosunkowo najłatwiej zaobserwować zjawisko integrowania społeczności lokalnej wokół boiska. Dotyczy to szczególnie świąt lokalnych (religijnych - odpusty; świeckich - dni miejscowości), w które zwyczajowo wpisywane są atrakcje w postaci zawodów sportowych. Godziny meczów ustalane są wówczas z kluczowymi postaciami życia społecznego (np. księdzem lub wójtem) i odpowiadają swoistemu porządkowi świętowania.

Zważywszy na to, że rywalizacja wytypowanych do badania klubów piłkarskich odbywała się de facto w tym samym czasie, wyznaczonym ustalanymi odgórnie (z niewielką możliwością modyfikacji przez działaczy klubów) terminarzami, zapoznanie się z kilkumiesięcznym planem rozgrywek stanowiło główną czynność po określeniu obszaru badań. Dopiero analizując terminy wydarzeń ligowych z udziałem wstępnie wytypowanych klubów (spełniających założone warunki doboru), można było podjąć próbę nawiązania pierwszego kontaktu celem uzyskania zgody i doprecyzowania warunków „wejścia” badacza w przestrzeń działalności klubu. Zadania tego nie ułatwiał fakt opóźnionego ataku zimy roku 2013, przez co zmianie uległy daty inauguracji większości lig amatorskich. Opracowany kilka miesięcy wcześniej harmonogram wyjazdów należało więc modyfikować ad hoc. W praktyce szansa deskrypcji podstawowych aktywności piłkarskich istniała przez kilkanaście (ściśle określonych) dni w przeciągu całego okresu realizacji projektu (w założeniu obejmującego jeden sezon rozgrywkowy). Autor, świadomy wycinkowości tak prowadzonej eksploracji, zdecydował, że obserwacja danego obiektu obejmie przede wszystkim te spotkania piłkarskie, w których klub pełni rolę gospodarza (nie zawsze jednak było to możliwe, stąd podróże za/z drużyną), a więc skupia zainteresowanie lokalnej społeczności i generuje wzmożo- ną aktywność kibiców. W trakcie jednego weekendu (jednej kolejki spotkań piłkarskich) obserwację uczestniczącą realizowano $\mathrm{w}$ tej samej miejscowości - realia logistyczne nie sprzyjały szybkiemu przemieszczaniu się między oddalonymi o kilkanaście kilometrów boiskami. Trzeba podkreślić, że przy ustalaniu kalendarium wyjazdów istotny okazał się również czynnik dogodności, wzmiankowany chociażby przez Uwe Flicka (2011: 59-60). Możliwości logistyczne (kwestia łatwości dojazdu komunikacją publiczną z najbliższego ośrodka miejskiego), pozytywna reakcja głównych działaczy (gotowych na rozmowę z badaczem każdego proponowanego dnia) oraz korzystny układ rozgrywek (obejmujący choćby mecze derbowe, cechujące się wysoką intensywnością emocji, a co za tym idzie - rozbudowanym konglomeratem fenomenów wartych obserwacji) okazały się ważnym kryterium doboru konkretnych obiektów badania. Niemniej - jak się okazało - nawet najskrupulatniej zaprojektowany plan wyjazdów nie gwarantuje bezproblemowego przebiegu badania. Autor zmuszony został definitywnie zrezygnować z ekspedycji do jednego z wytypowanych klubów piłkarskich w województwie mazowieckim, ponieważ jego lider w ostatniej chwili cofnął zgodę na wizytę badawczą w najdogodniejszym (de facto jedynym możliwym) terminie. Powodem okazało się wesele (oraz $t z w$. poprawiny) jednego z zawodników, na które zaproszono większość drużyny. Lider klubu w momencie pierwszego kontaktu z badaczem zapomniał o tym wydarzeniu (bez wattpienia istotnym dla społeczności klubowej). Zorientowawszy się w ostatniej chwili o kolizji terminów, poinformował telefonicznie, że przewiduje utrudniony dostęp do respondentów oraz brak możliwości przeprowadzenia wywiadów pogłębionych z piłkarzami w ciągu weekendu (co ciekawe, mecze wskazanego zespołu nie zostały odwołane). W konsekwencji utraconego terminu zabrakło cza- 
su na dodatkowe wizyty badawcze w rundzie wiosennej 2013 roku, w tym na uczestnictwo w jubileuszu 25-lecia istnienia jednego z rozpatrywanych w ramach studium klubów.

Wydaje się, że problem ograniczeń temporalnych $\mathrm{w}$ dobie pandemii ( $w$ zależności od natężenia obostrzeń i szybkości wychodzenia z kryzysu zdrowotnego) oraz spowodowanej nią niestabilności społeczno-ekonomicznej będzie eskalował. W okresie tak zwanego zamknięcia gospodarki, wiosną 2020 roku, zawieszono rozgrywki na wszystkich poziomach ligowych krajowej piłki - części z nich nie dokończono, uznając wyniki z rundy jesiennej (spotkało się to z ożywioną dyskusją w lokalnych środowiskach piłkarskich nt. transparentności przepisów regulujących awanse i spadki). Wraz z luzowaniem obostrzeń nastąpiła (w niektórych ligach) kumulacja zaległych spotkań i zagęszczenie terminarzy. Większość organizatorów rywalizacji zainicjowała kolejny sezon zmagań $\mathrm{w}$ terminach najwcześniejszych z możliwych, zakładając groźbę kolejnego lockdownu (stąd dążenie do względnie szybkiego zakończenia następnego cyklu rozgrywkowego) lub czasowego wyłączenia części klubów z przyczyn sanitarnych (zakażenia zawodników itp.). Elastyczność terminarzy prawdopodobnie wpisała się już na stałe w rzeczywistość sportową. Postulowana w poprzednich paragrafach skrupulatna analiza ligowego harmonogramu oraz planowanie logistyki pobytu mogą okazać się niewystarczające dla sprawnego przeprowadzenia studiów przypadku. Stąd rada praktyczna, aby eksploracje terenowe realizować w pierwszej fazie rozgrywek piłkarskich (okres letni) oraz multiplikować obiekty badania - tak, aby wobec niemożności prowadzenia obserwacji w jednej miejscowości, łatwy do uruchomienia pozostawał wariant alternatywny. Zasadne wydaje się też ograniczenie długości jednorazowego pobytu w te- renie oraz precyzyjne ukierunkowanie procesu pozyskiwania danych (podejście problemowe). Zawęzi to wprawdzie paletę stosowanych technik badawczych (zmniejszy różnorodność materiałów empirycznych) oraz spowoduje wzrost kosztów (większa liczba ekspedycji), jednak w sytuacjach awaryjnych ustrzeże repozytorium przed cmentarzyskiem analitycznie nieprzydatnych danych, tudzież brakiem istotnych.

\section{Zdobycie zaufania (problem wejścia w przestrzeń klubową)}

Trudności w zaplanowaniu eksploracji terenowej czyniły wszelkie doraźne podróże do wytypowanych miejscowości wysoce nieracjonalnymi. Choć obserwacja zawodów piłkarskich przed nawiązaniem kontaktu z członkami klubu niosłaby szereg korzyści, nie było pewności, że liderzy organizacji zdecydują się na udział w badaniu. W takiej sytuacji ekspedycja terenowa miałaby znacznie mniejsze walory opisowo-analityczne, a środki finansowe przeznaczone na podróż zostałby de facto zmarnowane. Stąd badacz starał się z odpowiednim wyprzedzeniem uzyskać deklarację uczestnictwa wytypowanych klubów w badaniu. Pierwszy kontakt odbywał się telefonicznie - w trakcie bezpośredniej rozmowy z liderem danego klubu proszono o pomoc w realizacji przedsięwzięcia. Liderów identyfikowano na podstawie danych będących w posiadaniu związku piłki nożnej (projekt zrealizowano przed wejściem w życie przepisów RODO, toteż uzyskanie numeru kontaktowego nie stanowiło większej trudności). Trzeba podkreślić, iż autor nie korzystał z prywatnych znajomości, wynikających z wieloletniej pracy społecznej w środowisku piłkarskim. Pierwszego kontaktu z działaczami nie cedował również na inne, odpowiednio ustosunkowane $\mathrm{w}$ terenie badań, osoby. $\mathrm{W}$ trakcie rozmowy telefo- 
nicznej przekazywano przedstawicielom klubów podstawowe informacje: cel badania (nie literalnie, a w kategoriach aplikacyjnych: „opis działalności klubów pozwoli efektywniej wspierać rozwój polskiego piłkarstwa") oraz afiliację badacza. Ponadto sondowano dogodny termin pobytu oraz szanse na ewentualne wsparcie logistyczne (szczególnie odnośnie do transportu na miejsce noclegu, nieraz oddalone od siedziby drużyny piłkarskiej). Co istotne dla wywarcia dobrego wrażenia: liderowi klubu pozostawiono czas do namysłu i ostateczne potwierdzenie woli uczestniczenia $\mathrm{w}$ badaniu. Potwierdzenie uzyskiwano $\mathrm{w}$ drugiej rozmowie telefonicznej, na ogół jeszcze tego samego dnia. Zasada transparencji celów (ograniczona do niezbędnego minimum) pozwalała niejako wejść w relację partnerską z członkami organizacji - badacz zyskiwał zaufanie i ograniczał reaktywność osoby wprowadzającej w przestrzeń działania danego klubu (por. Hammersley, Atkinson 2000: 270).

Bezpośrednie spotkanie $\mathrm{z}$ liderem (piastującym na ogół formalną funkcję w strukturze organizacji) następowało tuż po przybyciu badacza do miejscowości, w której klub miał siedzibę. Dochodziło do niego na przystanku autobusowym (jeśli odległość od obiektu sportowego była znaczna), na boisku (gdy planowano szybko przeprowadzić pierwszy wywiad), w urzędzie gminy (ze względu na dostępność), w rodzinnym domu działacza (jeśli dojazd do miejscowości okazywał się dogodny, a wieś cechowała spójna zabudowa). Lider stawał się kluczowym informatorem oraz "opiekunem badacza” (por. Lofland i in. 2009: 72-78). Pierwszą rolę wyznaczała newralgiczna dla dalszych analiz, a niedostępna w Internecie, wiedza o organizacji oraz jej członkach (dostęp do tej wiedzy stanowił priorytet pierwszych dni pobytu $\mathrm{w}$ terenie). Informacje pozyskane od lidera umożliwiały względnie szybką identyfikację osób predestynowanych do kolejnych wywiadów pogłębionych (poszukiwano: najstarszych członków klubu, osób wyróżniających się aktywnością, piłkarzy spoza miejscowości, najaktywniejszych kibiców itp.), jak również determinowały wiodące wątki rozmów (np. jubileusz klubu, zabiegi o nowe boisko, konflikty „z drużyną zza miedzy”). Do zadań informatora należało zaproponowanie terminu i miejsca przeprowadzenia wywiadów (badacz odznaczał się $\mathrm{w}$ tym względzie skrajną elastycznością) oraz podanie numeru telefonu rozmówców (lider zapowiadał kontakt). Informatora proszono ponadto o udostępnienie dokumentacji w postaci sprawozdań, terminarzy, protokołów, uchwał zarządu. Jednakże dane te uzyskiwano na ogół nie w formie oryginalnej, lecz przetworzonej (i prawdopodobnie istotnie skróconej). Do wglądu badacza przekazywano spisane odręcznie lub wydrukowane „raporty” dotyczące na przykład liczby członków, rodzajów ponoszonych wydatków, wyników spotkań ligowych. Źródła zastane okazały się niezwykle ubogie, co mówiło wiele o podejściu działaczy do kwestii biurokratycznych.

Istotną dla sprawnego przebiegu eksploracji terenowej była nadana liderowi klubu rola „opiekuna badacza”. Dzięki poddaniu się owej „opiece” badacz niwelował nieufność respondentów oraz związane $\mathrm{z}$ nią ograniczenia $\mathrm{w}$ gromadzeniu materiałów, rzadziej dochodziło też do negatywnych zaburzeń $\mathrm{w}$ relacjach $\mathrm{z}$ respondentami. Posiadanie opiekuna stanowiło warunek sine qua non wejścia w najbardziej poufną przestrzeń klubowych interakcji. Amatorski klub piłkarski należy bowiem traktować jako "trudnodostępny układ społeczny" (Lofland i in. 2009: 51-52). Trudność dostępu nie dotyczy w tym przypadku wyższych, sformalizowanych szczebli organizacyjnych, ale niższych, opartych na relacjach nieformalnych - wyznaczonych przestrzenią 
szatni dla zawodników (chroniona przed oglądem osób z zewnątrz, nienależących do grupy, nieutrzymujących kontaktów z piłkarzami, „obcych”) oraz zasięgu pozasportowych relacji (sąsiedzi, koledzy z pracy i szkoły, członkowie rodziny).

Obrana przez badacza strategia pozyskiwania „opiekuna” zmierzała do zaaranżowania publicznej rozmowy z liderem klubu lub wspólnego uczestnictwa w choćby jednym momencie skupienia grupy (sytuacja społeczna z udziałem piłkarzy, działaczy, kibiców - np. trening, „wieczór pod sklepem”). Ponadto lidera-opiekuna proszono o wcześniejsze zaanonsowanie wizyty badacza wśród członków klubu. Spotkanie inicjujące kontakty z miejscowymi kibicami (jeśli tworzyli zorganizowaną grupę), tudzież wejście badacza na teren miejscowego boiska, odbywało się zawsze w towarzystwie lidera-opiekuna. Obecność w przestrzeni nieformalnych aktywności zawodników (nie tylko szatnia czy budynek klubu, ale też np. autobus w trakcie podróży na mecz) poprzedzano pytaniem o zgodę - badacz nigdy nie przebywał $\mathrm{w}$ pomieszczeniach klubowych sam. Podobnie rzecz miała się z obecnością na ławce rezerwowych, skąd prowadzono część obserwacji. Przesiadywanie w miejscu zarezerwowanym z definicji dla piłkarzy i sztabu drużyny poprzedzano przybyciem na mecz $\mathrm{w}$ towarzystwie lidera. Obecność na ławce $\mathrm{w}$ trakcie zawodów wiązała się $\mathrm{z}$ ograniczeniami $\mathrm{w}$ stosowaniu technik gromadzenia danych - nie przeprowadzano wówczas rejestrowanych wywiadów, nie wykonywano zdjęć osób wpisanych do protokołu. Opiekunowie badacza mieli świadomość, że jako osoba spoza społeczności lokalnej będzie on utożsamiany przez niektórych kibiców miejscowej drużyny z fanami rywali. Fakt ten bezpośrednio nie niósł negatywnych konsekwencji, jednak dostrzegana przez meczową publiczność mobilność badacza (przemieszczenie się wokół płyty boiska, rozmowy w kibicami, służbami porządkowymi, wykonywanie fotografii itp.) mogła w momencie spotęgowania sportowych emocji prowadzić do scysji słownych lub innych, niekomfortowych sytuacji (por. Hughson 1998). Aby temu zapobiec, działacze pożyczali badaczowi na czas spotkania ligowego - jeśli pozwalały na to okoliczności - szalik kibicowski. Nosząc ten atrybut wiernego fana (niemożliwy do zdobycia poza społecznością lokalną i produkowany w niskich seriach), badacz był postrzegany jako „swój”. Brak szalika powodował bezbronność $w$ innych niż meczowe sytuacjach. Przykładowo: w jednej z wiosek doszło do sprzeczki z młodzieżą w trakcie fotografowania plakatu zapraszającego na zawody ligowe, a umieszczonego na drzwiach lokalnej pizzerii. Młodzi ludzie nie dawali wiary, iż zdjęcia miały służyć celom badawczym; nie wierzyli też w znajomość autora (dla nich zupełnie obcego) z zawodnikami i liderem miejscowej drużyny. Dopiero bezpośrednio wykonany do prezesa klubu telefon pozwolił rozładować napięcie i kontynuować gromadzenie materiałów fotograficznych w przestrzeni wsi bez obaw o bezpieczeństwo.

Po ostatnim gwizdku zawodów zaufanie członków klubu oraz aktywnych kibiców (jeśli takowi byli) do badacza na ogół istotnie wzrastało. Przekładało się to na większą gotowość do wzięcia udziału w wywiadach pogłębionych oraz ograniczenie zaburzeń (nienaturalnych zachowań, momentów ciszy itp.) $\mathrm{w}$ trakcie obserwowanych przez badacza sytuacji nieformalnych, jak choćby pomeczowych spotkań integracyjnych. Wydatne ułatwienie w podtrzymaniu zaufania stanowiła znajomość „,żargonu szatni” - terminów i określeń stosowanych przez piłkarzy, chociażby w odniesieniu do zasad gry i rytuałów meczowych (por. Konecki 2000). Nie oznacza to jednak, iż nieufność - lub wyraźny dystans - responden- 
tów zostawały całkowicie wyeliminowane. Grupą szczególnie trudnodostępną, niechętną rozmowie, pozostawały osoby wspierające klub finansowo (przeważnie lokalni przedsiębiorcy). Pomoc działacza-opiekuna w zaaranżowaniu wywiadów okazywała się tu nad wyraz mało skuteczna. W ocenie badacza wynikało to z drażliwej tematyki rozmów, odnoszącej się nie tyle do samej działalności klubu, co do praktyk pomocowych upowszechnionych w środowisku lokalnym (wsparcie często w oparciu o niesformalizowane porozumienia, pozostające poza oficjalną księgowością i kontrolą zewnętrzną). Utożsamianie badacza z instytucją publiczną z dużego miasta sprawiało, że w optyce biznesmenów uchodził on za potencjalnego kontrolera skarbowego. Większość informacji o mechanizmach donacji klubów uzyskano poprzez intensywny wywiad off the record (przeważnie zdawkowy, krótkotrwały, nieraz przy okazji rozmów z innymi kategoriami respondentów).

W odniesieniu do sytuacji postpandemicznej należy założyć, że nieufność wobec osób spoza społeczności lokalnej - cechująca dotąd pewne kategorie aktorów społecznych - stanie się powszechna. Podłożem nieufności będą przy tym lęki pierwotne (tj. obawy o zdrowie), trudniejsze do złagodzenia w oparciu o znajomość z liderem klubu. Prawdopodobnie ograniczony zostanie dostęp do przestrzeni podstawowych aktywności drużyn piłkarskich - wejście do szatni, pomieszczeń dla sędziów czy nawet przebywanie na ławce rezerwowych zostanie poddane restrykcjom i kontroli. Wspólne podróże na mecze wyjazdowe także staną się niemożliwe (zwłaszcza z zespołami juniorskimi). Za takim obrotem sprawy - za skrajną proceduralizacją zawodów piłkarskich - przemawiają decyzje organizatorów rozgrywek piłkarskich, podejmowane już po zniesieniu głównych obostrzeń związanych z pierwszą falą pandemii w 2020 roku. Wraz z „odmrażaniem sportu” zaczęto wprowadzać wewnętrzne zalecenia mające zminimalizować ryzyko zakażeń i oddalić widmo odpowiedzialności prawnej za powstanie ognisk chorobowych. Instrukcje dotyczyły zarówno kwestii stricte sanitarnych, jak i liczby osób przebywających na obiekcie sportowym (co wydaje się kuriozalne w warunkach wiejskiego, otwartego boiska). Znane autorowi są też przypadki sporządzania imiennych list kibiców. Nie wnikając w skuteczność i skalę stosowania wyżej wymienionych rozwiązań w niższych ligach, należy przyjąć, że badacz - jako osoba spoza środowiska piłkarskiego - będzie traktowana przez członków klubów ze znaczną dozą podejrzliwości. Postawa taka wydawać się może groteskowa, zważywszy, że w futbolowe zmagania wpisana jest styczność fizyczna na boisku (styczność obarczona znacznym ryzykiem zakażeń). Trzeba tu jednak zaznaczyć, że prywatne znajomości między piłkarzami z nieodległych klubów - spotkania w pracy, szkole, galerii handlowej - minimalizują odczucie lęku. Dużo groźniejsza wydaje się rozmowa "face to face” z obcym, do tego przybyszem z odległego miasta. W takiej sytuacji rozwiązaniem stać się może zmiana formy realizacji wywiadów pogłębionych - przejście na tryb zdalny za pomocą popularnych aplikacji, które w kontekście ucyfrowienia wsi nie są już novum. Za ostateczną receptę na nieufność uznany będzie negatywny wynik testu na obecność SARS Cov-19. Pamiętać jednak należy, że troska o własne bezpieczeństwo powinna dotyczyć również badacza. Dlatego unikanie fizycznego kontaktu, zachowanie dystansu społecznego, śmielsze korzystanie z zapośredniczonych technik gromadzenia danych (fotografia, etnografia wirtualna, analiza materiałów zastanych) zyskują status podstawowych dyrektyw metodologicznych, choć istotnie obniżają poznawczy walor sensualnej styczności z obiektami badania, pozwa- 
lającej uchwycić zmysłami to, co nie podlega werbalizacji (por. Sparkes 2016).

\section{Rozstrzygnięcie kwestii etycznych (dobro obiektów badania a bogactwo danych)}

Uzyskanie zaufania respondentów nie zwalnia z dochowania staranności na gruncie etyki prac badawczych. Ułatwieniem $\mathrm{w}$ tym względzie stać się mogą dokumenty obowiązuje w środowisku socjologicznym, jak również własna intuicja oparta na zmyśle moralnym i doświadczeniach osobistych (Angrosino 2009: 141). Dylematy ujawniające się $\mathrm{w}$ trakcie omawianej eksploracji terenowej badacz starał się odnosić do wytycznych Kodeksu Etyki Socjologa Polskiego Towarzystwa Socjologicznego (2012) oraz własnych wspomnień z członkostwa w Ludowych Zespołach Sportowych. Czyniło to procedurę badawczą momentami zbieżną z metodą autoetnograficzną. Niemniej autor nie konstruował eksplikacji w oparciu o swoją pamięć i doświadczenia, nie włączał też własnych wspomnień do repozytorium projektu (por. Winkler 2017).

Spośród imperatywów stosowanych w prezentowanym projekcie wymienić należy - splątane ze sobą - zachowanie poufności oraz troskę o dobro obiektów badania. Fundamentalne dyrektywy znalazły odzwierciedlenie nie tylko $\mathrm{w}$ procesie anonimizacji wywiadów pogłębionych (co samo w sobie nastręcza trudności w przypadku sformalizowanych, małych grup społecznych, gdzie np. funkcje organizacyjne piastuja pojedyncze osoby), ale także sporządzania notatek z obserwacji uczestniczącej. Fakt przebywania za kulisami klubu (w szatni, świetlicy wiejskiej czy miejscowym barze) pozwalał stosunkowo łatwo uzyskać informacje drażliwe, przy tym niezwiązane bezpośrednio z celami badania. Obligowało to badacza do zachowania szczególnej pieczy nad tym, co usłyszał i zauważył. W sytuacjach, których clou stanowi szeroko rozumiana integracja, a nieodzownym elementem pozostaje konsumpcja alkoholu, dochodzi do „otwarcia” piłkarzy i kibiców. Zważywszy na to, że cechą członkostwa $\mathrm{w}$ wiejskich klubach piłkarskich jest dualizm ról społecznych (przynależność do klubu pokrywa się z przynależnością do społeczności lokalnej) narracje off the record dotyczyły nieraz sfery życia prywatnego, sąsiedzkiego, oceny pracy innych instytucji życia zbiorowego, czasem niemożliwych do zweryfikowania plotek z pogranicza sensacji i życia towarzyskiego, jak również relacji z aktów przemocy (bójek, „wjazdów”) w lokalnym środowisku kibicowskim (por. Pearson 2009). Skrupulatny zapis wszystkich dialogów, żartów - w tym choćby niecenzuralnych, prześmiewczych przyśpiewek pod adresem głównych rywali z boiska lub miejscowych notabli - komentarzy we wspomnianych okolicznościach byłby ewidentnym działaniem na szkodę jednostek, które wcześniej obdarzyły badacza zaufaniem i w stanie odurzenia, w sposób nieskrępowany, dzieliły się wiedzą niedotyczącą wprost ich aktywności klubowych. Unaocznia się tu problem uzyskania w pełni świadomej zgody na wykorzystanie udzielonych informacji oraz kwestia rozeznania przez respondenta konsekwencji własnych słów i zachowań przy obniżonym stopniu samokontroli - badacz nie jest zwolniony od odpowiedzialności za interlokutorów (Palmer 2010: 429-431). Z drugiej strony bogata wiedza o społeczno-kulturowym kontekście działalności klubu piłkarskiego oraz o warunkach codziennego życia w danej miejscowości stanowi wartość samą w sobie. Pozwala lepiej zrozumieć niuanse zachowań w oficjalnych - meczowych - sytuacjach (np. powód sprzeczki w szatni czy animozje między liderami klubu). Ważąc za i przeciw, autor podjął decyzje o pominięciu w dzienniku terenowym zasłyszanych plotek, kłótni czy wypowiedzi nie- 
związanych bezpośrednio z aktywnością w klubie. W dzienniku nie znalazły się też cytaty zawierające wulgaryzmy oraz informacje o życiu osobistym aktorów społecznych.

Wśród pozyskanych informacji poufnych znajdowały się częstokroć również te odnoszące się do naruszeń przepisów prawa sportowego (wzmianki $\mathrm{z}$ drugiej ręki na temat pozaregulaminowych kontaktów z arbitrami, kulis uzyskiwania uprawnień trenerskich, historie "lewusów” - piłkarzy bezprawnie uczestniczących $\mathrm{w}$ rozgrywkach niższych lig). Wiedzą tą działacze i piłkarze dzielili się na ogół tuż przed zakończeniem przez autora pobytu w danej wiosce. Ujawnienie szczegółów wydarzeń zaistniałych - co istotne - w przeszłości lub osnucie wokół nich wiodących wątków analitycznych mogło skutkować negatywnymi konsekwencjami dla całej organizacji. Autor w zgodzie z dyrektywami etycznymi zobowiązywał się do zabezpieczenia przede wszystkim interesu badanych obiektów, nie zaś dobra społeczeństwa rozumianego ogólnie (Angrosino 2010: 157). Nie oznacza to, że wśród rezultatów przedsięwzięcia powinna znaleźć się namacalna korzyść dla uczestniczących w nim klubów. W trakcie realizacji badań autor nie wchodził więc w rolę „,adwokata” organizacji: czy to w sporach z lokalną władzą (w których argument naukowy byłby cenny), czy też $\mathrm{w}$ relacjach z podmiotami uznawanymi za zdolne zabezpieczyć finansowo dany klub. Zdarzało się bowiem, że działacze usilnie prosili o podkreślenie $\mathrm{w}$ rozmowie z miejscowym wójtem, że ich klub wyróżnia się aktywnością spośród innych organizacji społecznych, a tym samym zasługuje na wyższą dotację lub też pilny remontu boiska („,lobbowanie” stanowić miało formę wdzięczności za pomoc logistyczną w trakcie pobytu badacza w danej miejscowości). Można więc stwierdzić, że dla wielu działaczy sportowych uczestnictwo ich klubu w projekcie stanowiło okazję do zyskania przewagi na lokalnym polu instytucjonalnym (np. nad innymi organizacjami pozarządowymi). Przeświadczenie o mocy sprawczej „naukowca z Warszawy" powodowało również, że kilkukrotnie piłkarze i kibice wnosili, aby „poinformować Bońka lub Muchę" (prezesa PZPN lub ówczesną minister sportu) o „prawdziwych” problemach małych, wiejskich klubów, tudzież o fatalnym w ich odczuciu funkcjonowaniu terenowych struktur piłkarskich. Badacz, dążąc do podtrzymania partnerskiej relacji z klubowymi aktywistami, wskazywał wówczas przyszłe korzyści z wdrożenia rekomendacji wykoncypowanych dzięki badaniom. Jednocześnie nalegał, by działacze tymczasowo nie nagłaśniali (nie promowali w środowisku lokalnym) swego uczestnictwa w projekcie (por. Bjärsholm i in. 2018: 226).

Pandemia koronawirusa przynosi nowe oraz intensyfikuje istniejące dylematy natury etycznej w badaniach jakościowych. Rzeczywistość przesiąknięta strachem przed zakażeniem i poczuciem braku kontroli nad własnym życiem obliguje naukowców do jeszcze większego wyczulenia na kwestie drażliwe, mogące godzić w interes ludzi i instytucji poddawanych badawczemu oglądowi. Powstają już zestawy dyrektyw dostosowane do wyzwań ery postpandemicznej, jak na przykład Model 4P (Place, People, Principles, Precedents), zakładający gruntowne rozeznanie kontekstu realizowanych badań, stworzenie odpowiednio doświadczonego zespołu, nieustanną orientację na zdefiniowane zasady w czasie ekspedycji badawczych, odnoszenie się do dylematów etycznych zaistniałych w przeszłości (Calia i in. 2020: 6-9). W odniesieniu do terenowych studiów nad sportem wiejskim wymienione dyrektywy przyjąć mogą formę zobowiązania do: uprzedniego zapoznania się -W oparciu o ogólnodostępne informacje - z sytuacją epidemiczną $w$ danej miejscowo- 
ści oraz klubie (w tym z warunkami realizowania wywiadów oraz obserwacji uczestniczącej w szatni, na boisku itp.), zaangażowania do zespołu badawczego osób w pełni świadomych ryzyka zakażenia oraz gotowych samodzielnie podejmować decyzje badawcze w środowisku sportowym (np. zaniechania pozyskiwania danych $\mathrm{w}$ miejscach niepoddanych dezynfekcji), bieżącej wymiany doświadczeń z uczestnikami innych przedsięwzięć socjologicznych realizowanych na obszarach wiejskich.

W rzeczywistości postpandemicznej z pewnością jednak nie ulegna zanegowaniu podstawowe, uniwersalne imperatywy, choćby opisana wyżej zasada poufności. Potencjalne okazje do ich stosowania zaczęto dostrzegać tuż po zakończeniu lockdownu wiosną 2020 roku. Amatorskie kluby piłkarskie dotowane ze środków publicznych nie mogły prowadzić w tym czasie normalnej działalności, zaś brak wydatków groził zmniejszeniem kwoty przyszłego wsparcia (lub oczekiwaniem zwrotu już przyznanego). Zainicjowano więc strategie zaradcze (np. sztuczne generowanie kosztów tuż po zniesieniu restrykcji). Zważywszy na ryzyko kryzysu ekonomicznego, tematyka finansowania amatorskiego sportu pozostanie nadal frapująca, acz kłopotliwa $\mathrm{w}$ deskrypcji z racji jeszcze większej nieufności względem osób postrzeganych jako rewizorzy. Nowym zagadnieniem badawczym może stać się zdrowie zawodników i działaczy wiejskich klubów piłkarskich. Informacje na ten temat $z$ definicji należą do wyjątkowo drażliwych - ich ujawnienie może okazać się szkodliwe dla jednostki (ostracyzm), ale niezbędne dla dobra grupy. Co więcej, społeczny odbiór choroby - ze względu na wciąż żywe elementy kultury tradycyjnej - pozostaje inny na wsi i w mieście (por. Szpak 2018). Dyrektywy etyczne przewidziane do zastosowania w realiach dużej, narzucającej anonimowość metropolii niekoniecz- nie dadzą się wdrożyć w małej wsi, której mieszkańcy znają się całe życie (szczególnie że uciążliwość pandemii jest $\mathrm{w}$ tych środowiskach czasem skrajnie różna). Konkludując, autor wyraża przekonanie, że $\mathrm{w}$ erze postpandemicznej nie zaistnieją wyzwania etyczne niemożliwe do przezwyciężenia w oparciu o fundamentalne zasady pracy badawczej lub po prostu zdrowy rozsądek.

\section{Podsumowanie}

Dylematy przytoczone $\mathrm{w}$ niniejszym tekście ilustrują złożoność społeczno-kulturowego fenomenu, jakim jest sport wiejski i działalność amatorskich klubów piłkarskich. Zestaw trudności możliwych do zaistnienia $\mathrm{w}$ trakcie jego opisu i analizy nie będzie mieć nigdy charakteru zamkniętego. Finalnie więc każdy socjolog sportu podejmujący trud opracowania jakościowego studium osadzonego w kontekście rustykalnym zmuszony zostanie do pokonania specyficznych (zależnych $\mathrm{w}$ dużej mierze od kontekstu, gdyż wieś pozostaje kategorią niejednorodną) przeszkód. Rzeczą pożądaną jest, aby wcześniej samodzielnie je zidentyfikował i zaproponował adekwatne, teoretycznie spójne i etycznie wyważone rozwiązania. Niezmienna pozostanie tym samym podstawowa zasad współczesnego stylu badań etnograficznych, w którym szczególny nacisk kładzie się na refleksyjność i „,świadomość tożsamości sytuacyjnych". Wymaga ona nieustannego krytycznego namysłu nad ,ja" badacza, traktowanego jako "ludzki instrument badawczy” (Guba, Lincoln 2009: 306).

Dynamika przeobrażeń społeczno-kulturowych w Polsce, zmieniające się uwarunkowania rozwoju kultury fizycznej, rosnąca profesjonalizacja organizacji sportowych, wreszcie nowe realia (ledwie zarysowane $\mathrm{w}$ niniejszym tekście) prowadzenia 
rozgrywek w dobie postpandemicznej - wszystko to niewątpliwie czyni eksploracje wiejskich boisk przygodą nieprzewidywalną, a przez to niezmiernie ciekawą. Obserwacja instytucji popularyzujących kulturę fizyczną poza miastem - zwłaszcza przez pryzmat różnych podejść metodologicznych - może przyczynić się do odkrycia genetyki i tendencji procesu usportowienia całego polskiego społeczeństwa (por. Wohl 1975). Trudności metodologiczne sygnalizowane przez autora nie powinny zniechęcać do wysiłku. Warto mieć na uwadze, że okoliczności metodologicznie swoiste, a wręcz za-

\section{Bibliografia}

Angrosino Michael (2009) Obserwacja w nowym kontekście. Etnografia, pedagogika i rozwój problematyki społecznej. Przełożył Filip Rogalski [w:] N. K. Denzin, Y. S. Lincoln, red., Metody badań jakościowych, t. 2. Warszawa: Wydawnictwo Naukowe PWN, s. 129-151.

Angrosino Michael (2010) Badania etnograficzne i obserwacyjne. Przełożyła Maja Brzozowska-Brywczyńska. Warszawa: Wydawnictwo Naukowe PWN.

Bjärsholm Daniel i in. (2018) Ethical considerations in researching sport and social entrepreneurship. „European Journal for Sport and Society", vol. 15, no. 3, s. 216-233.

Burdyka Konrad (2019) Między zagroda a boiskiem. Studium aktywności wiejskich klubów sportowych. Warszawa: Wydawnictwo IFiS PAN.

Calia Clara i in. (2020) Ethical challenges in the COVID-19 research context: a toolkit for supporting analysis and resolution. „Ethics \& Behavior", s. 1-16.

Dobrowolski Kazimierz (1966) Studia nad życiem społecznym i kultura. Wrocław, Warszawa, Kraków: Zakład Narodowy im. Ossolińskich, Wydawnictwo PWN.

Evans Adam B. i in. (2020) Sport in the face of the COVID-19 pandemic: towards an agenda for research in the sociology of sport. „European Journal for Sport and Society", vol. 17, no. 2, s. 85-95. skakujące często stają się „zdarzeniami kluczowymi", wymuszającymi pogłębioną refleksję nad sposobem gromadzenia danych, a czasem wręcz nad meritum rozważań. W tym kontekście pandemia SARS Cov-19 może sprowadzić na badaczy iluminację - odświeżyć spojrzenie na zdawać by się mogło gruntowanie przeanalizowane już zagadnienia. Więcej: dać może impuls do przewartościowania dotychczasowych paradygmatów i wiodących twierdzeń socjologii sportu (por. Evans i in. 2020). Wypada wierzyć, że środowisko socjologiczne szansę tę z odwagą wykorzysta.

Fine Gary A., Abramson Corey M. (2020) Ethnography in the time of Covid-19. Vectors and the vulnerable. „Etnografia e ricerca qualitativa, Rivista quadrimestrale”, vol. 2, s. 165-174.

Flick Uwe (2011) Projektowanie badania jakościowego. Przełożył Paweł Tomanek. Warszawa: Wydawnictwo Naukowe PWN.

Gibbs Graham (2011) Analizowanie danych jakościowych. Przełożyła Maja Brzozowska-Brywczyńska. Warszawa: Wydawnictwo Naukowe PWN.

Guba Egon G., Lincoln Yvonna S. (2009) Kontrowersje wokót paradygmatów, sprzeczności i wyłaniające się zbieżności. Przełożyła Monika Bobako [w:] N. K. Denzin, Y. S. Lincoln, red., Metody badań jakościowych, t. 1. Warszawa: Wydawnictwo Naukowe PWN, s. 281-313.

Hammersley Martyn, Atkinson Paul (2000) Metody badań terenowych. Przełożył Sławomir Dymczyk. Poznań: Wydawnictwo Zysk i S-ka.

Heinemann Klaus (1989) Wprowadzenie do socjologii sportu. Warszawa: Centralny Ośrodek Metodyczny Studiów Nauk Politycznych.

Hughson John (1998) Among the thugs. The 'New Ethnographies' of Football Supporting Subcultures, "International Review for the Sociology of Sport", vol. 33, no. 1, s. 43-57.

Konecki Krzysztof (2000) Studia z metodologii badań jakościowych. Teoria ugruntowana. Warszawa: Wydawnictwo Naukowe PWN. 
Kossakowski Radosław, Antonowicz Dominik, Szlendak Tomasz (2012) Duszacy dym odpalonych rac. O wyzwaniach w etnografii subkultury kibiców pitkarskich. „Przegląd Socjologii Jakościowej”, t. 8, nr 3, s. 6-29.

Lofland Lyn H. i in. (2009) Analiza układów społecznych. Przewodnik metodologiczny po badaniach jakościowych. Przełożyły Anna Kordasiewicz, Sylwia Urbańska, Monika Żychlińska. Warszawa: Wydawnictwo Naukowe Scholar.

Lutyński Jan (2000) Metody badań społecznych. Wybrane zagadnienia. Łódź: Łódzkie Towarzystwo Naukowe.

Palmer Catherine (2010) Everyday risks and professional dilemmas: fieldwork with alcohol-based (sporting) subcultures. "Qualitative Research" vol. 10, no. 4, s. 421-440.

Pearson Geoff (2009) The researcher as hooligan: where 'participant' observation means breaking the law. „International Journal of Social Research Methodology", vol.12, no. 3, s. 243-255.

Polskie Towarzystwo Socjologiczne (2012) Kodeks etyki socjologa [dostęp 21 sierpnia 2020 r.]. Dostępny w Internecie: ‘https://pts. org.pl/wp-content/uploads/2016/04/kodeks.pdf).
Sparkes Andrew C. (2016) Ethnography as a sensual way of being. Methodological and representational challenges [w:] Molnar Gyozo, Purdy Laura G., eds., Ethnographies in Sport and Exercise Research. New York, London: Routledge, s. 45-58.

Stempień Jakub R. (2018) Wokół pytań o polska socjologię sportu. „Studia Socjologiczne”, nr 1, s. 171-193.

Szpak Ewelina (2018) „Chory człowiek jest wtedy jak coś go boli”. Społeczno-kulturowa historia zdrowia i choroby na wsi w Polsce Ludowej, wyd. 2. Warszawa: Instytut Historii PAN.

Winkler Ingo (2017) Doing Autoethnography: Facing Challenges, Taking Choices, Accepting Responsibilities. "Qualitative Inquiry", vol. 24 , no. 1 , s. 1-12.

Wohl Andrzej (1975) Some Remarks on the Methodology of Research on the Sociology of Sport. „International Review of Sport Sociology", vol. 10, no. 2, s. 5-32.

Wright Mills Charles (2007) Wyobraźnia socjologiczna. Przełożyła Marta Bucholc. Warszawa: Wydawnictwo Naukowe PWN.

\section{Cytowanie}

Burdyka Konrad (2021) Kilka uwag o terenowym badaniu amatorskich klubów piłkarskich (w nastającej erze postpandemicznej). „Przegląd Socjologii Jakościowej", t. 17, nr 1, s. 12-25 [dostęp dzień, miesiąc, rok]. Dostępny w Internecie: ‘www.przegladsocjologiijakosciowej.org〉. DOI: http://dx.doi.org/10.18778/1733-8069.17.1.02

\section{Some Notes on the Field Study of Amateur Football Clubs (in the Coming Post-Pandemic Era)}

Abstract: Empirical studies in the field of sports sociology are characterized by an extraordinary difficulty of realization in situ, which is manifested by limited access to research material and limited possibility of its comparisons. As Klaus Heinemann (1989) pointed out in his classic study, these problems result from (a) the diversity of models of modern sport and forms of its social rooting, and (b) the specificity of sports organizations - currently polyfunctional, often operating in extremely diversified social environments. The aim of the article is to present selected methodological problems that occurred during the ethnographic study of amateur football clubs operating in the countryside of Poland. The author also makes an attempt to relate the experience gained from the realization of this venture with the post-pandemic situation. The article can thus be treated as a voice in the discussion on the usefulness of qualitative tools in the study of contemporary sport.

Keywords: football club, rural areas, methodology, pandemic 